\title{
THE FATE OF A TROPICAL RAINFOREST IN NIGERIA: ABEKU SECTOR OF OMO FOREST RESERVE
}

OJO L.O.

\author{
Department of Environmental \\ Management and Toxicology, \\ University of Agriculture, \\ Abeokuta, Nigeria
}

Received: $23 / 6 / 03$

* to whom all correspondence should be addressed:

Accepted: 6/4/04

e-mail: yembum@yahoo.com

\begin{abstract}
Sixteen permanent sample plots of one hectare each, established in 1985 at Abeku sector of Omo Forest Reserve, South west Nigeria by the European Economic Community/ Nigeria Federal Government (High Forest Monitoring Plots Project) (EEC/HFMPP) were used for this study. The plots were re-enumerated in 1987. Further assessment took place in 1997 and 2000 respectively for the purpose of assessing the floristic characteristics of the plots. The present study aims at assessing the floristic composition during the sampling years. Out of the original 16 plots only eleven and nine plots were available for assessment in 1997 and 2000 respectively. The remaining plots had been converted to plantations of arable and cash crops. The numbers of tree species encountered were 98, 109, 95 and 71 for 1985, 1987, 1997 and 2000 enumerations respectively. Also 28,31, 29 and 23 families were encountered in 1985, 1987, 1997 and 2000 respectively. In terms of density, basal area and spread, the ten most abundant species are Diospyros iturensis (Plant nomenclature follows Hutchinson and Dalziel (1954-72); Keay (1989) and Lowe and Soladoye (1990)), (DIAL),Tabernaemontana pachysiphon (TAPA), Octolobus angustatus (OLAN), Strombosia pustulata (SBPU), Diospyros dendo (DIDE), Diospyros suaveolens (DISU), Drypetes gossweileri (DRGO), Rothmania hispida (ROHI), Hunteria unbellata (HUUM) and Anthonotha aubryanum (ASAU) and the six most prominent families are Ebenaceae, Apocynaceae, Euphorbiaceae, Sterculiaceae, Olacaceae and Rubiaceae .Mean number of stems per hectare ranges from 400.44 to 1134.0 for the small trees $(5-20 \mathrm{~cm} \mathrm{dbh}) ; 89.78$ to 174.25 for the medium trees $(20-40 \mathrm{~cm} \mathrm{dbh})$ and 8.33 to 17.06 for the large trees $(>40 \mathrm{~cm}$ dbh) Mean basal area per hectare ranges from $4.94 \mathrm{~m}^{2}$ to $8.81 \mathrm{~m}^{2}$ for the small trees, $5.4 \mathrm{~m}^{2}$ to $9.63 \mathrm{~m}^{2}$ for the medium trees and $4.64 \mathrm{~m}^{2}$ to $9.04 \mathrm{~m}^{2}$ for the large trees.

Inverse of Simpson diversity indices range between 15.1 to 16.27 for the small tree, 13.43 to 16.37 for the medium trees and 23.44 to 26.34 for the large trees. The highest mean values per hectare of these parameters were found in 1987 enumeration, while the least values were found in the year 2000 enumeration. This variability may not be due only to the number of plots available for enumeration alone, but also as a result of poaching in the remaining plots before the 2000 enumeration. The study recommends that conscious efforts should be made to protect and maintained the permanent sample plots not only to reduce the possibility of encroachment but also to achieve the objective for which they were established which was to elucidate the dynamics and growth pattern of the natural rainforest. There is also a need for international assistance to achieve this.
\end{abstract}

\section{INTRODUCTION}

Tropical forests are among the richest and most complex terrestrial ecosystems supporting a variety of life forms of not less than half of all species on earth (Phillips, 1996) and a tremendous intrinsic ability for self-regeneration 
if properly maintained. However, many of these forests are losing these properties due mainly to interference by anthropogenic actions. The rate of deforestation has been estimated variously for different parts of the world. In Nigeria, the annual rate of deforestation has been estimated as ranging between 3\% to $5 \%$ (Ojo, 1993). However, these may just be guess estimate and far from reality. It has been espoused that forests have been recently affected by large scale anthropogenic and natural changes (Philips, 1996) and better understanding of the ecological changes in natural forest depends on progress in monitoring network of tropical forest plots. One of the major purposes of permanent sample plots (PSPs) is to monitor forest diversity and processes over time period in order to enhance better understanding of both local and large scale pattern in forest ecology.

Early long term assessment of the Nigerian rainforest had been made possible by Forestry Research Institute of Nigeria (FRIN) through permanent sample plots (PSP) established at different parts of the county in the early 1920s (Okali and Ola-Adams, 1987). Unfortunately, some of these plots had not been maintained in recent years. A network of 80 permanent sample plots of one hectare each were established within the rainforest of southern Nigeria between 1985 and 1987 (Table 1) by the European Economic Community/Nigerian Federal Department of Forestry High Forest Monitoring Project (HFMP). The objectives of the HFMP include the periodic monitoring for information on tree population dynamics. All the plots had been reexamined after two years of establishment. Reports based on the two samplings in all the plots had been made by Ojo (1990, 1996). However, plots at Abeku sector of Omo forest reserve had additional re-sampled in 1997 and 2000. The present study is based on the four samplings at Abeku sector of Omo Forest Reserve in 1985, 1987, 1997 and 2000 with the aim of assessing the developments in the forest. This is expected to be achieved by analysing plot parameters including tree density and basal area, species and family composition, tree species diversity etc. at different sampling periods.

\section{MATERIALS AND METHODS Study Area}

Omo forest reserve is located between $6^{\circ} 35^{\prime}$ to $7^{\circ} 05^{\prime \prime} \mathrm{N}$ and $4^{\circ} 19^{\prime \prime}$ to $4^{\circ} 40^{\prime \prime} \mathrm{E}$ in the South-West of Nigeria, about $135 \mathrm{~km}$ North-East of Lagos and $80 \mathrm{~km}$ East of Ijebu-Ode. It covers an area of about 130,500 hectares. Abeku sector is located in the north-eastern end of Omo forest reserve. (Figure 1) The vegetation and other general description of the study site had been carried out by various authors (Okali and Ola-Adams, 1987; Ojo, 1990; Ojo, 1996; Ola-Adams et al., 1998; Ola-Adams, 1999).

\section{Vegetation}

The vegetation of Omo Forest Reserve is a mixed moist semi-deciduous rainforest. This can be distinguished into a dry evergreen mixed deciduous forest in the northern part and a wet evergreen forest in the southern part. With the exception of the 640 hectare Strict Nature Reserve, now a Biosphere Reserve at the centre of the forest reserve, most of the forest are disturbed with a substantial parts converted to tree plantations. The plant families with the most abundant individuals include Araceae, Compositae, Ebenaceae, Lilliaceae, Papilionoideae, Poaceae, Rubiaceae and Violaceae. The most common tree species include Diospyros spp., Drypetes spp., Strombosia pustulata, Rinorea dentata and Voacanga africana.

\section{Topography, Geology and Soil}

The topography of the sites varies widely from nearly flat to rolling. About $80 \%$ of the sites are well-drained into the watershed of River Omo the major river that traverses the sites. The uneven topography is characterised by numerous small hills which are dissected by tributaries of the Omo, Shasha and Oluwa Rivers. This unevenness has been attributed to past geological events. The area was once composed of sedimentary rocks, probably sandstone, of varying coarseness. A period of volcanic activity in the past heated these rocks to such an extent that they became viscous and flowed.

In many places schist (mainly low grade muscovite-biotite) and gueinsses can be found. Good flow banding and folding are also visible usually on outcrops on top of hills. In other places homogeneous outcrops of granodiorite can be found as well as quartzites outcrops in one or two localities. As a result the metamorphic rock has produced terrain that is quite resistant to the actions of physical and chemical weathering. About $80 \%$ of the sites are well-drained into the watershed of river Omo. The sites are made up of several soil types but they all belong to the tertiary sediments. Most of the soils are heavily leached, being Oxic. 



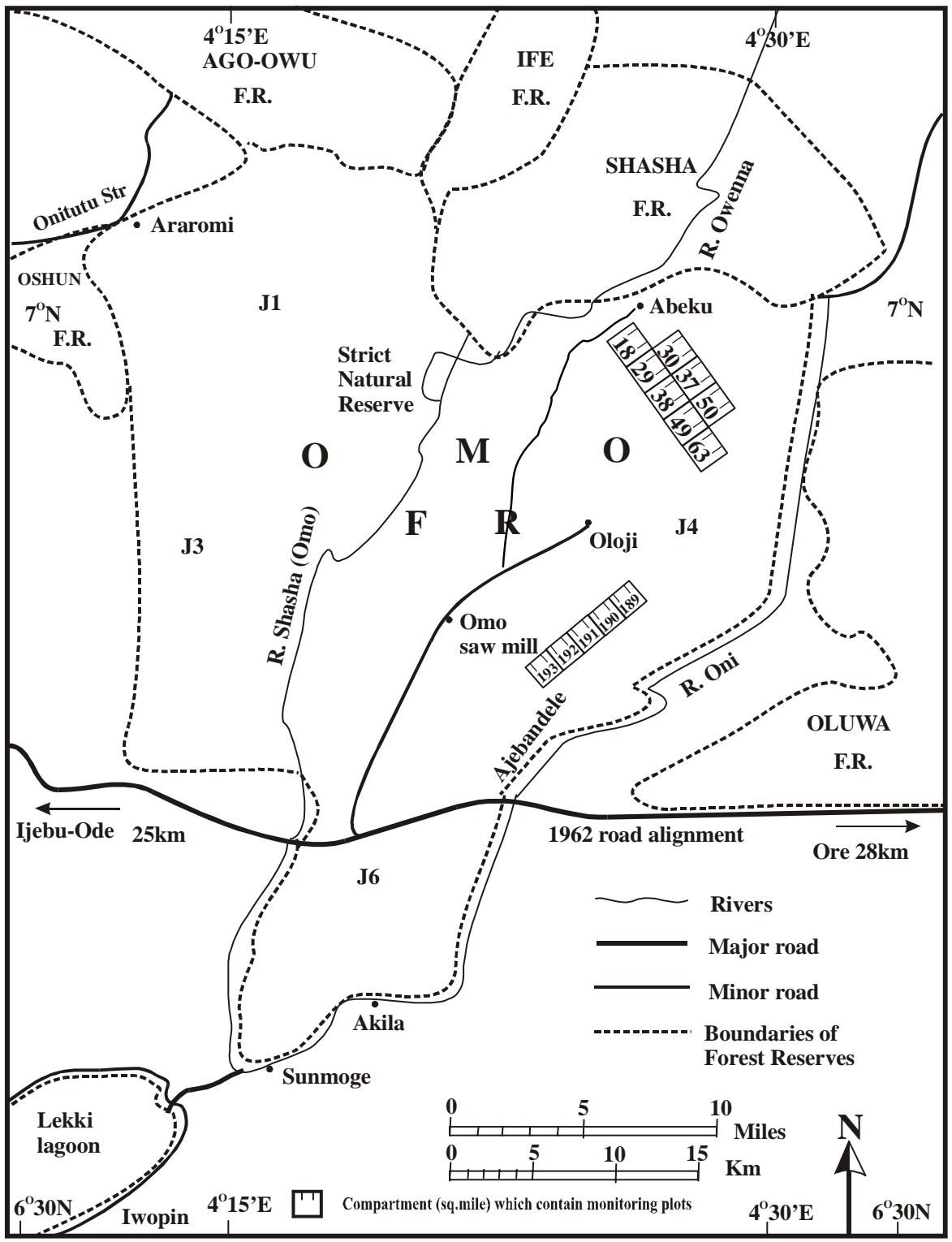

Figure 1. Map of Omo Forest Reserve showing the position of Abeku

Tropudalfs and Rhodic Paleudults. The most commonly occurring series are Alagba, Owode and Oteyyi The Alagba series are well drained and usually located near slope top and nearly level summit areas of the project site. They are deep soils without stones and concretions. The soil texture is usually sandy loam topsoil and sandy clay subsoil. The soils are derived from ferruginous sandstones.

The Owode series are also well drained. They occur in gently sloping upper slope sites, occasionally with steep-sided ironstone capped hills. The Oteyyi series are concretionary soils. They contain a large amount of medium sized rounded concretionary materials, though occasional larger lumps may be found. They occur on moderate or gentle slopes in middle and upper slopes sites. The top soil is usually dark brown clayey-sand and the subsoil is usually reddish brown sandy clay.

\section{Data Collection and Analyses:}

Sixteen plots of one hectare each comprising plots 11-26 of the High Forest Monitoring Plots (HFMP) (Ojo, 1990) located in compartments $18,29,30,37,38,49,50$, and 63 at Abeku sector of Omo forest reserve were enumerated in 1985 and re-enumerated in 1987 (Table 1). However as a result of human activities especially farming, not all the sixteen plots were available for further enumeration in 1997 and 2000 (Table 1). Each plot is one hectare in extent $(40 \mathrm{~m}$ by $250 \mathrm{~m}$ ) and offset perpendicularly $50 \mathrm{~m}$ from the reference baseline. 
Table 1. Location of High Forest Monitoring Plots within the rainforest of southern Nigeria

\begin{tabular}{|l|l|l|l|l|}
\hline & Location & $\begin{array}{l}\text { Number } \\
\text { of plots }\end{array}$ & $\begin{array}{l}\text { Year of } \\
\text { establishment }\end{array}$ & $\begin{array}{l}\text { Year(s) of } \\
\text { remeasurement }\end{array}$ \\
\hline 1 & Omo (Sawmill sector) & 10 & 1985 & 1987 \\
\hline 2 & Omo (Abeku sector & 16 & 1985 & $1987,1997,2000$ \\
\hline 3 & Oban East & 10 & 1987 & 1989 \\
\hline 4 & Oban West & 10 & 1987 & 1989 \\
\hline 5 & Owan & 13 & 1986 & 1988 \\
\hline 6 & Sapoba & 21 & 1986 & 1988 \\
\hline
\end{tabular}

The centreline of each plot is demarcated and marked at intervals of $50 \mathrm{~m}$. Floristic data comprising mainly diameter at breast height (dbh) were collected from each plot at three levels:

Small trees $5-20 \mathrm{~cm}$ dbh measured within $2.5 \mathrm{~m}$ either side of the centreline.

Medium trees $20-40 \mathrm{~cm}$ measured within $5 \mathrm{~m}$ either side of the centreline.

Large trees $>40 \mathrm{~cm}$ dbh in the entire plot.

Thus, the three tree size classes: small trees, 5-20 $\mathrm{cm} \mathrm{dbh}$; medium trees, 20-40 $\mathrm{cm}$ dbh and large trees, $>40 \mathrm{~cm}$ dbh were measured in different percentages of the plot $(12.5 \%, 25 \%$ and $100 \%$ respectively). The enumeration data per plot and at each year were summarised into frequency and basal area tables using FORTRAN program STANDTAB and STANDBA (Lowe R.G., Personal communications). Each table comprised the scientific names, codes, family names and frequency or basal area at the three tree size classes. These plot tables were then collated for further statistical analyses including the following:

(a) Correlation analysis was carried out to compare the frequencies and basal areas of the size classes at the measuring periods.

(b) Simpson diversity index (I): In order to explore the diversity in terms of species heterogeneity taking into consideration the number of species and the density of individual species, Simpson diversity indices were computed for each size classes at the different measuring periods. The inverse of the original Simpson index was used so as to remove the ambiguity in the original Simpson index, hence the higher the value of I, the greater the heterogeneity, thus:

$$
I=\frac{N(N-1)}{\sum_{i=1}^{q} n_{i}\left(n_{i}-1\right)}
$$

Where: $\mathrm{N}=$ total number of individual enumerated

$q=$ number of different species enumerated

$\mathrm{n}=$ number of individuals of ith species enumerated

(c) Sorensen, similarity index (SI): In order to compare the species composition during the measuring periods, Sorensen's similarity indices were computed between pair periods. Only the nine plots available for all the four sampling periods were used, thus:

$$
S I=\frac{a}{a+b+c} \times 100
$$

Where: $\mathrm{SI}=$ percentage similarity index

$\mathrm{a}=$ number of species present in both sampling years

$b=$ number of species present in the first sampling year and not in the second

$\mathrm{c}=$ number of species present in the second sampling year and not in the first.

\section{RESULTS AND DISCUSSION}

The full list of tree species enumerated with their families and total frequencies for the four measuring periods (1985, 1987, 1997 and 2000) are presented in Appendix 1. The summaries of floristic variables assessed are presented in Table 3.

\section{Floristic composition Tree species}

There were 98, 109, 95 and 71 plant species enumerated in 1985, 1987, 1997 and 2000 respectively. The increase from 1985 to 1987 was due to more species being identified in the 1987 enumeration but the subsequent decrease in 1997 and 2000 are due to long interval between 
Table 2. Plots available for enumeration in subsequent years of measurement at Abeku sector of Omo Forest Reserve, Nigeria

\begin{tabular}{|c|c|c|c|c|}
\hline \multirow{2}{*}{$\begin{array}{c}\text { Plot } \\
\text { code } \\
\text { number }\end{array}$} & \multicolumn{4}{|c|}{ Measurement years } \\
\hline & 1985 & 1987 & 1997 & 2000 \\
\hline 11 & $\sqrt{ }$ & $\sqrt{ }$ & $\sqrt{ }$ & $\sqrt{ }$ \\
\hline 12 & $\sqrt{ }$ & $\sqrt{ }$ & n.av & n.av \\
\hline 13 & $\sqrt{ }$ & $\sqrt{ }$ & $\sqrt{ }$ & $\sqrt{ }$ \\
\hline 14 & $\sqrt{ }$ & $\sqrt{ }$ & $\sqrt{ }$ & $\sqrt{ }$ \\
\hline 15 & $\sqrt{ }$ & $\sqrt{ }$ & $\sqrt{ }$ & $\sqrt{ }$ \\
\hline 16 & $\sqrt{ }$ & $\sqrt{ }$ & n.av & n.av \\
\hline 17 & $\sqrt{ }$ & $\sqrt{ }$ & n.av & n.av \\
\hline 18 & $\sqrt{ }$ & $\sqrt{ }$ & n.av & n.av \\
\hline 19 & $\sqrt{ }$ & $\sqrt{ }$ & $\sqrt{ }$ & $\sqrt{ }$ \\
\hline 20 & $\sqrt{ }$ & $\sqrt{ }$ & n.av & n.av \\
\hline 21 & $\sqrt{ }$ & $\sqrt{ }$ & $\sqrt{ }$ & n.av \\
\hline 22 & $\sqrt{ }$ & $\sqrt{ }$ & $\sqrt{ }$ & n.av \\
\hline 23 & $\sqrt{ }$ & $\sqrt{ }$ & $\sqrt{ }$ & $\sqrt{ }$ \\
\hline 24 & $\sqrt{ }$ & $\sqrt{ }$ & $\sqrt{ }$ & $\sqrt{ }$ \\
\hline 25 & $\sqrt{ }$ & $\sqrt{ }$ & $\sqrt{ }$ & $\sqrt{ }$ \\
\hline 26 & $\sqrt{ }$ & $\sqrt{ }$ & $\sqrt{ }$ & $\sqrt{ }$ \\
\hline
\end{tabular}

$\sqrt{ }:$ Plots measured

n.av: Plots already converted to plantations of arable and cash crops and hence not available for enumeration

measurement during which the plots had been encroached and some plots completely lost to cash and arable crop farmers (Table 2). This no doubt affected the diversity of the tree species. The ten most abundant plant species in 1985 are Diospyros iturensis (DIAL),Tabernaemontana pachysiphon (TAPA), Octolobus angustatus (OLAN), Strombosia pustulata (SBPU), Diospyros dendo (DIDE), Diospyros suaveolens (DISU), Drypetes gossweileri (DRGO), Rothmania hispida (ROHI), Hunteria umbellata (HUUM) and Anthonotha aubryanum (ASAU). The ten species account for over $54 \%$ of the total tree frequency (Table 4). The composition of the ten most abundant species did not change drastically in subsequent measurements. Thus in 1987, 1997 and 2000, the ten most abundant tree species represent $63.2 \%, 66.6 \%$ and $64.5 \%$ of the frequency of all trees respectively. With regards to basal area, two clear distinction are noticeable. First, some upper storey large trees such as Erythrophleuem ivorensis (ERIV) and Terminalia superba (TESU) had been added to the list of the first ten species. This is not surprising since basal area defines area occupied by individual species. The second distinction is that Strombosia pustulata (SBPU) consistently occupied the first position in all the four measuring periods. This may be attributed to the large number of individuals present and the ability of the tree species to grow to a fairly large sized tree. Nevertheless, the ten largest trees at each enumeration accounted for $47.8 \%, 47.2 \%$, $56.6 \%$ and $50.8 \%$ of the total basal area during 1985, 1987, 1997 and 2000 enumerations respectively (Table 4).

\section{Tree species and family distribution}

The spread of species among plots, their percentage and cumulative percentages at each measuring time are presented in Table 5. The percentages were based on the number of plots available for measurement. Thus 16 plots in 1985 and 11 and 8 plots in 1997 and 2000 respectively. The results show that only $32.65 \%$ and $35.77 \%$ of the species were present in 8 out of the i6 plots in 1985 and 1987 while over $35 \%$ of the species occur in less than three plots. The situation is somewhat the same in 1997 where less than $40 \%$ of the species were present in five out of 11 plots. In 2000, no single tree species occur in all the nine plots, while $33 \%$ of the species were present in four out of the nine plots enumerated. For the sparsely distributed species, 
Table 3. Summary of sample plots parameters at Abeku sector of Omo Forest Reserve, Nigeria

\begin{tabular}{|l|c|c|c|c|}
\hline \multirow{2}{*}{ Parameters measured } & \multicolumn{4}{|c|}{ Years of Measurement } \\
\cline { 2 - 5 } & $\mathbf{1 9 8 5}$ & $\mathbf{1 9 8 7}$ & $\mathbf{1 9 9 7}$ & $\mathbf{2 0 0 0}$ \\
\hline Number of plots & 16 & 16 & 11 & 9 \\
\hline Numbers of Species & 98 & 109 & 95 & 71 \\
\hline Numbers of Families & 28 & 31 & 29 & 23 \\
\hline Mean stems per hectare: & & & & \\
5-20cm dbh & 1134.0 & 1167.0 & 864.73 & 400.44 \\
20-40cm dbh & 171.75 & 174.25 & 128.0 & 89.78 \\
$>40 \mathrm{~cm}$ dbh & 17.06 & 17.94 & 14.73 & 8.33 \\
Total per & 1322.81 & 1359.19 & 1007.46 & 498.56 \\
\hline Mean basal area & & & & \\
hectare: & 8.28 & 8.81 & 7.88 & 4.94 \\
$5-20 \mathrm{~cm}$ dbh & 9.31 & 9.63 & 7.24 & 5.4 \\
20-40cm dbh & 9.04 & 9.0 & 8.03 & 4.64 \\
$>40 \mathrm{~cm}$ dbh & 26.63 & 27.43 & 23.15 & 14.97 \\
Total & & & & \\
Simpson diversity indices & & & & \\
$5-20 \mathrm{~cm}$ dbh & 16.05 & 16.27 & 15.72 & 15.10 \\
20-40cm dbh & 16.37 & 16.30 & 14.06 & 13.43 \\
$>40 \mathrm{~cm}$ dbh & 24.27 & 26.34 & 24.23 & 23.44 \\
Total & 18.07 & 18.41 & 17.43 & 17.75 \\
\hline
\end{tabular}

not less than $19 \%$ had occurrence in only one plot. These sparsely or "restricted" species are sources of concern in relation to conservation of genetic resources in the face of reducing areas of forested land.

A total of 32 tree families were encountered during the study. Of these 22 families were common in each of the four enumerations (Table 6). 31 families were enumerated in 1987 while 28, 29 and 23 families enumerated in 1985, 1997 and 2000. This meant that additional four families were discovered in 1987 while one family, Anacardiaceae disappeared after 1985 sampling. In 1985, the six families which account for over $86 \%$ of stand density with total density are Ebenaceae, Apocynaceae, Euphorbiaceae, Sterculiaceae, Olacaceae and Rubiaceae. The six have 7,6,16,4,1 and 9 species respectively. It is of interest to note that Olacaceae has only one specy i.e. Strombosia pustulata, it is still among the largest six families that dominate the landscape. The six families still dominate the landscape in subsequent enumerations accounting for $84.2,85.4$ and $77 \%$ of total density in 1987, 1997 and 2000. The four families enumerated in 1987 but not found in earlier enumeration in 1985 are Capparaceae, Guttiferae, Passiloraceae and Rhamnaceae. They have one species member each. They are the families of Bucholzia coriacea, Garcinia kola, Barteria fistulosa and Maesopsis emini. Unfortunately, except for Bucholzia coriacea, other three species were not encountered in 1997 and 2000. The decreasing number of species and families from 1987 through 1997 to 2000 indicates the extent of danger to the diversity of the natural forest due to dereservation and deforestation.

\section{Stand Density and Basal area}

Stand density per plot and size classes at each measuring periods are presented in Table 7 . Generally, as will be expected, mean density decreases from small trees to the larger trees. In 1985, mean density per plot ranges from 17.06, 117.75 to 1134.0 for large trees, medium trees to small trees respectively. In 1987, the trend is not different from that of 1985 but there is increase in the mean density per plot at all tree size classes.

Thus 1167.0, 174.25 and 17.94 for small, medium and large sized tress. Increase in the mean density per plot for the small trees in 1997 may be due to new recruitment to the minimum size class. For 1997 and 2000, there is general decrease in the mean density per plot. 
Table 4. Relative proportion (pi) of tree density and basal area of the ten most abundant species at different years of measurements

\begin{tabular}{|c|c|c|c|c|c|c|c|c|}
\hline \multicolumn{9}{|c|}{ (a) Tree density } \\
\hline & \multicolumn{2}{|c|}{1985} & \multicolumn{2}{|c|}{1987} & \multicolumn{2}{|c|}{1997} & \multicolumn{2}{|c|}{2000} \\
\hline & Species & pi & Species & pi & Species & pi & Species & pi \\
\hline 1 & DIAL* & 0.120 & DIAL & 0.114 & TAPA & 0.111 & TAPA & 0.123 \\
\hline 2 & TAPA & 0.103 & TAPA & 0.107 & SBPU & 0.104 & DIAL & 0.094 \\
\hline 3 & OLAN & 0.090 & OLAN & 0.091 & DIAL & 0.103 & SBPU & 0.093 \\
\hline 4 & SBPU & 0.087 & SBPU & 0.083 & OLAN & 0.091 & ASAU & 0.082 \\
\hline 5 & DIDE & 0.073 & DIDE & 0.066 & DIDE & 0.061 & OLAN & 0.056 \\
\hline 6 & DISU & 0.040 & DISU & 0.045 & ASAU & 0.046 & DIDE & 0.054 \\
\hline 7 & DRGO & 0.035 & DIPI & 0.038 & DISU & 0.046 & STRH & 0.039 \\
\hline 8 & ROHI & 0.032 & ASAU & 0.029 & DIPI & 0.038 & ROHI & 0.036 \\
\hline 9 & HUUM & 0.030 & ROHI & 0.029 & HUUM & 0.037 & DIPI & 0.034 \\
\hline 10 & ASAU & 0.028 & MCBA & 0.028 & ROHI & 0.029 & DISU & 0.034 \\
\hline$\sum$ & & 0.5486 & & 0.632 & & 0.666 & & 0.645 \\
\hline \multicolumn{9}{|c|}{ (b) Relative Basal area } \\
\hline & \multicolumn{2}{|c|}{1985} & \multicolumn{2}{|c|}{1987} & \multicolumn{2}{|c|}{1997} & \multicolumn{2}{|c|}{2000} \\
\hline & Species & pi & Species & pi & Species & pi & Species & pi \\
\hline 1 & SBPU & 0.089 & SBPU & 0.082 & SBPU & 0.107 & SBPU & 0.113 \\
\hline 2 & DIAL & 0.067 & DICR & 0.063 & ASAU & 0.054 & ASAU & 0.081 \\
\hline 3 & ERIV & 0.058 & DIAL & 0.062 & ERIV & 0.049 & ERIV & 0.060 \\
\hline 4 & TESU & 0.051 & ERIV & 0.048 & RIHE & 0.047 & DIAL & 0.043 \\
\hline 5 & DIDE & 0.042 & TESU & 0.047 & TESU & 0.046 & RIHE & 0.043 \\
\hline 6 & DISU & 0.038 & DISU & 0.045 & DISU & 0.039 & STRH & 0.039 \\
\hline 7 & MCBA & 0.036 & MCBA & 0.039 & DIDE & 0.035 & MICI & 0.032 \\
\hline 8 & HUUM & 0.031 & DIDE & 0.033 & HUUM & 0.032 & DISU & 0.031 \\
\hline 9 & SCCO & 0.029 & ASAU & 0.027 & STRH & 0.030 & HUUM & 0.031 \\
\hline 10 & RIHE & 0.027 & HUUM & 0.027 & TAPA & 0.028 & DIDE & 0.031 \\
\hline$\sum$ & & 0.4782 & & 0.472 & & 0.566 & & 0.508 \\
\hline
\end{tabular}

*: Full names of plants are provided in Appendix 1

Thus $864.73,128.0$ and 14.73 for small, medium and large trees in 1997 and 400.44, 89.79 and 8.33 for the three size classes in 2000. The decrease in these values in 1997 and 2000 were not only due to few plots enumerated but possibility of encroachment into the plots and outright conversion to plantations of monocultural tree crops and food crops as in plots 12, 16, 17 and 18 between 1987 and 1997 and plots 21 and 22 between 1997 and 2000. The stem basal area per plot and in the three tree size classes at the four measuring periods are presented in Table 8 . The pattern of distribution of basal area among the tree size classes is different from that of stem density. While stem density follows an inverted J, basal area increase with increasing tree size depending of course on the number of trees represented in the size classes. In 1985, the mean basal area per one hectare plot was $27.24 \mathrm{~m}^{2}$. This was made up of $8.28 \mathrm{~m}^{2}, 9.31 \mathrm{~m}^{2}$ and $9.04 \mathrm{~m}^{2}$ in the small, medium and large trees respectively. As in the tree density, the mean basal area per hectare in 1987 had increased to $27.43 \mathrm{~m}^{2}$ made up of 8.81 $\mathrm{m}^{2}, 9.93 \mathrm{~m}^{2}$ and $9.0 \mathrm{~m}^{2}$ in the three size classes respectively. Mean basal area per hectare in the 1997 and 2000 enumerations had decreased to $23.15 \mathrm{~m}^{2}$ and $14.97 \mathrm{~m}^{2}$ respectively (Table 8 ). From the stand density and basal area values for each plot, size class and years of enumeration, it is clear that the plots are heterogeneous. Student's t statistic computed showed that there is significant difference between the plots at $99 \%$ probability (Tables 7 and 8).

\section{Correlation between Measurement Periods}

The correlation matrices of both stand density 
Table5. Percentage distribution of tree species in the sample plots at different measuring periods at Abeku Sector of Omo Forest Reserve, Nigeria.

\begin{tabular}{|c|c|c|c|c|c|c|c|c|c|c|c|c|}
\hline \multicolumn{13}{|c|}{ Year s of measurement } \\
\hline & \multicolumn{3}{|c|}{1985} & \multicolumn{3}{|c|}{1987} & \multicolumn{3}{|c|}{1997} & \multicolumn{3}{|c|}{2000} \\
\hline $\begin{array}{l}\text { No of plots } \\
\text { present }\end{array}$ & Spp & $\%$ & c\% & Spp & $\%$ & c\% & Spp & $\%$ & c\% & Spp & & \\
\hline 16 & 10 & 10.204 & 10.204 & 9 & 8.2568 & 8.256 & & & & & & \\
\hline 15 & 1 & 1.0204 & 11.224 & 3 & 2.7522 & 11.00 & & & & & & \\
\hline 14 & 3 & 3.0612 & 14.285 & 2 & 1.8348 & 12.84 & & & & & & \\
\hline 13 & 6 & 6.1224 & 20.408 & 2 & 1.8348 & 14.67 & & & & & & 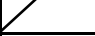 \\
\hline 12 & 1 & 1.0204 & 21.428 & 5 & 4.5871 & 19.26 & & & & & & \\
\hline 11 & 4 & 4.0816 & 25.510 & 4 & 3.6697 & 22.93 & 8 & 8.4210 & $8 . \$ 210$ & & & \\
\hline 10 & 3 & 3.0612 & 28.571 & 2 & 1.8348 & 24.77 & $3 / 7$ & 3.1578 & 11.578 & & 7 & \\
\hline 9 & 1 & 1.0204 & 29.591 & 4 & 3.6697 & 28.44 & 2 & 2.1052 & 13.684 & 0 & 0 & $0 \searrow$ \\
\hline 8 & 3 & 3.0612 & 32.653 & 8 & 7.3394 & 35.77 & 3 & 3.1578 & 16.842 & 4 & 5.633 & 5.6338 \\
\hline 7 & 7 & 7.1428 & 39.795 & 4 & 3.6697 & 39.44 & 2 & 2.1052 & 18.947 & $y$ & 5.633 & 11.267 \\
\hline 6 & 2 & 2.0408 & 41.836 & 6 & 5.5045 & 44.95 & 4 & 4.2105 & 23.157 & 4 & 5.633 & 16.901 \\
\hline 5 & 11 & 11.224 & 53.061 & 6 & 5.5045 & 50.45 & 10 & 10.526 & 33.684 & 5 & 7.042 & 23.943 \\
\hline 4 & 4 & 4.0816 & 57.142 & 9 & 8.2568 & 58.71 & 9 & 9.4736 & 43.157 & 7 & 9.859 & 33.802 \\
\hline 3 & 7 & 7.1428 & 64.285 & 9 & 8.2568 & 66.97 & 9 & 9.4736 & 52.631 & 5 & 7.042 & 40.845 \\
\hline 2 & 16 & 16.326 & 80.612 & 11 & 10.091 & 77.06 & 21 & 22.105 & 74.736 & 19 & 26.76 & 67.605 \\
\hline 1 & 19 & 19.387 & 100 & 25 & 22.935 & 100 & 24 & 25.263 & 100 & 23 & 32.39 & 100 \\
\hline TOTAL & 98 & 100 & & 109 & 100 & & 95 & 100 & & 71 & 100 & \\
\hline
\end{tabular}

and basal area at different periods of measurement are presented in Tables $7 \& 8$. In order to ensure proper comparisons, only the nine plots that were available throughout the study were used. For the stand density, the relationship between subsequent measurement was only significant at $99 \%$ for 1985 and 1987 and 1985 and 1997 while relationship between 1987 and 1997 and also between 1997 and 2000 were significant at $95 \%$. The other two size classes only have significant correlation at $99 \%$ between 1985 and 1997. The pattern is not different for basal area. The implications of this trend is that there had been a tremendous change in both the stand density and basal area and consequently on the stand structure.

\section{Diversity indices}

The results of the inverse of Simpson diversity indices are presented in Table 3. The inversion of Simpson formula is to avoid the ambiguity associated with the normal rendition of the formula. In the present form, the higher the value, the more heterogeneous the site.

Two patterns can be distinguished in the diversity indices, one across the years of measurement and the other along the tree sizes. For 1985 and 1987, the values increase with increasing tree size while the figures dropped for the medium trees in 1997 and 2000.

The indices for the total stem for each year of measurement are between the lowest and highest value. Across the measuring period, the diversity indices follows the same pattern as the stand density and basal area, increasing in 1987 but decreasing through 1997 to 2000. In 1985, diversity indices varies from $16.05,16.37$ to 24.27 for the small, medium and large trees respectively. The values in each class increase in 1987 varying from $16.27,16.30$ to 26.34 for the small, medium and large trees respectively. In 1997, the figures dropped to $15.72,14.06$ t 24.43 for the three size classes. There is further drop in the figures for 2000 thus $15.10,14.43,23.44$ for the tree.

\section{Similarity indices}

Sorensen/s similarity indices between pair sampling periods for the nine plots available during the four sampling periods are presented in Table 9. High values were found between 1985 and 1987 (86.46); 1987 and 1997 (88.120 and 1997 and 2000 (71.47), while least value was found between 1985 and 2000 (69.79). This trend of decreasing values with subsequent with subsequent sampling, thus, 1985 and 1987> 1985 and $1997>1985$ and 2000 further confirms that change in floristic composition is not only due to outright loss of some plots but also due to encroachment of the remaining plots.

\section{CONCLUSION}

The 1985 and 1987 values for the various parameters assessed showed that Abeku Sector of Omo Forest Reserve was a well stocked 


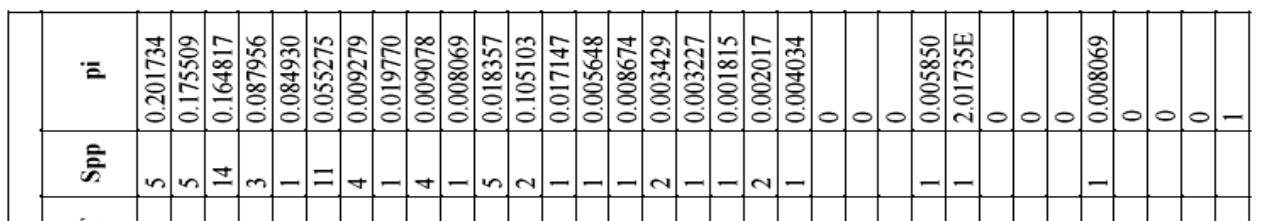

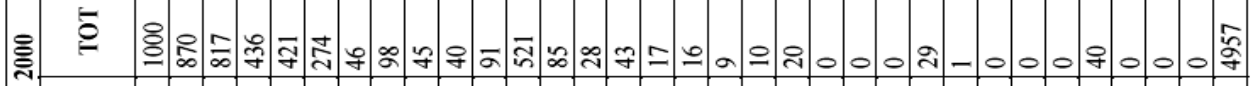
屋 至

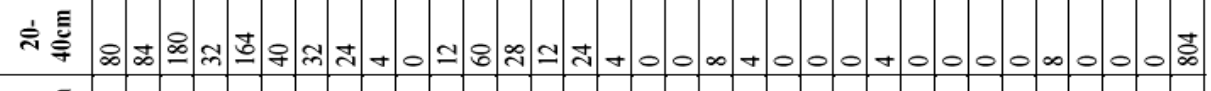
的言

â่

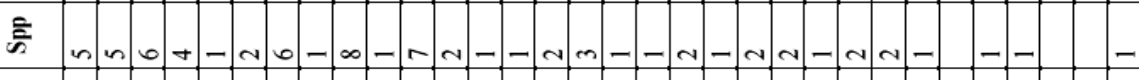

妾

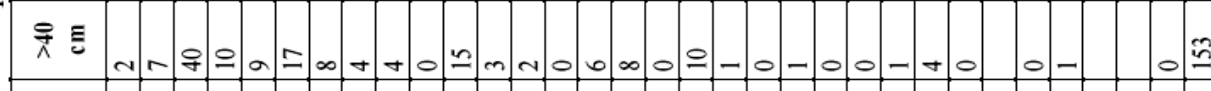

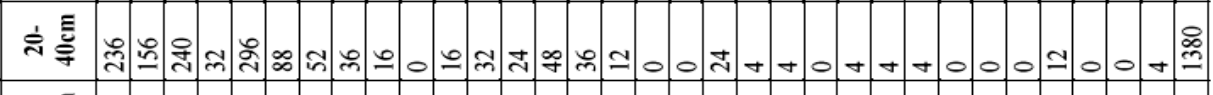

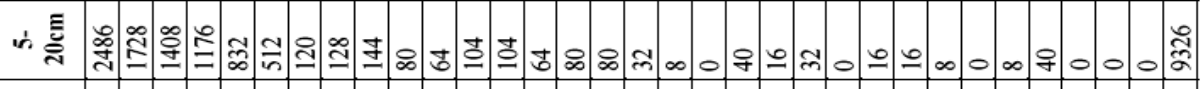

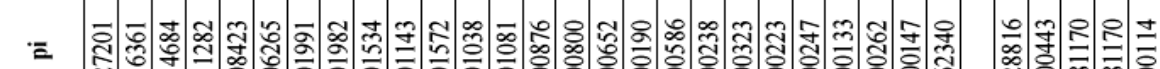
帘

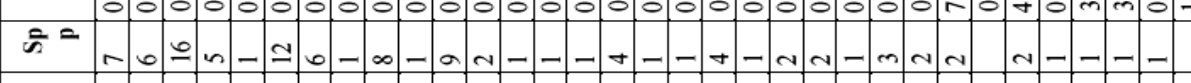

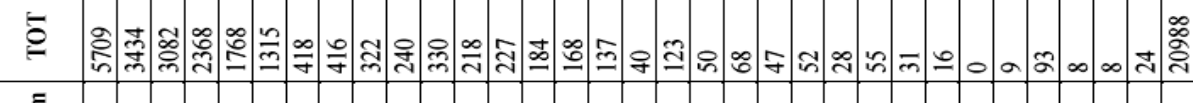
$\stackrel{\infty}{\square}$

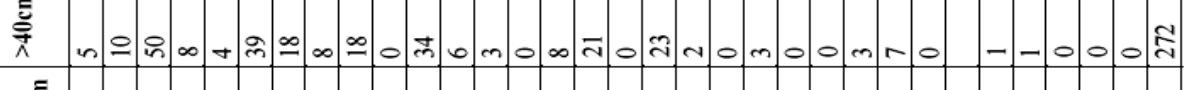
离言

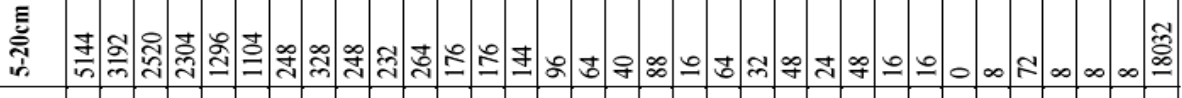

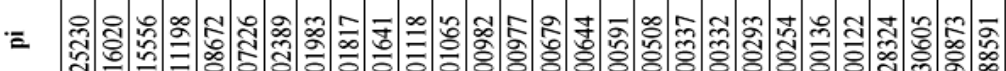
敋

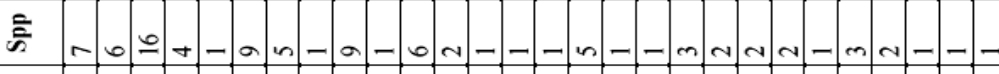

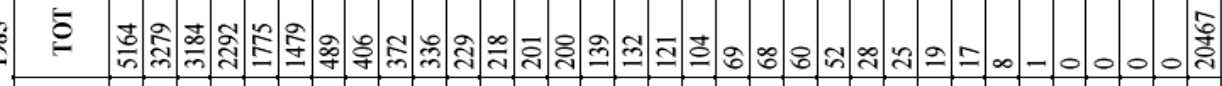

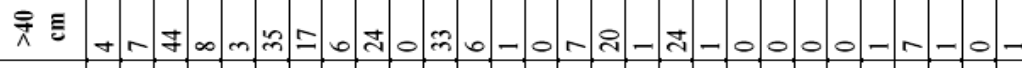

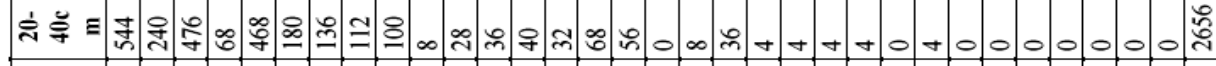

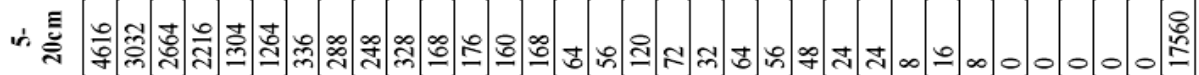

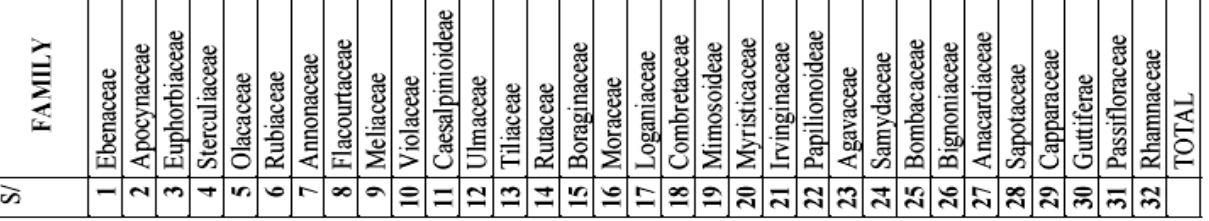



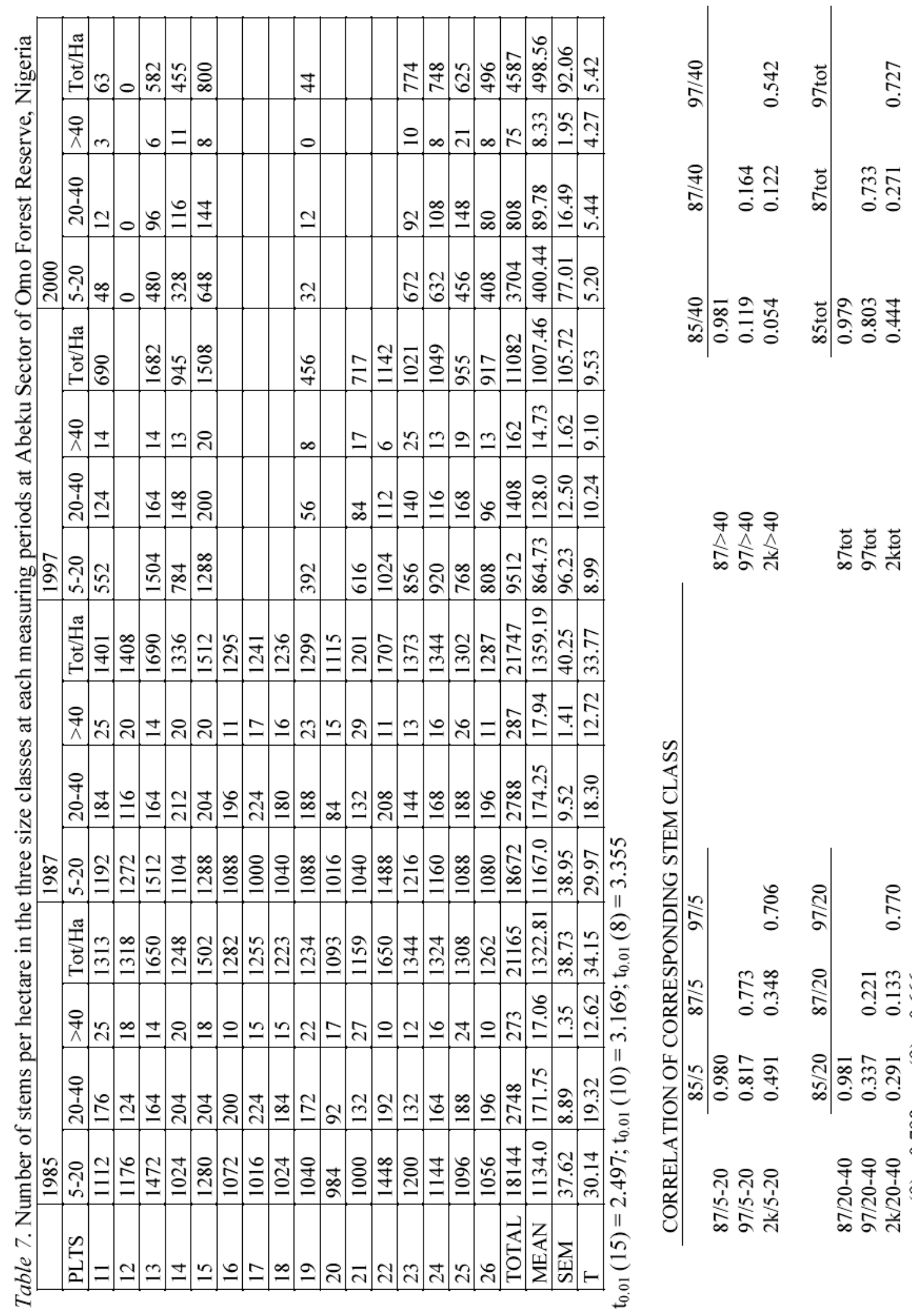

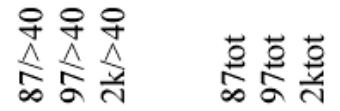

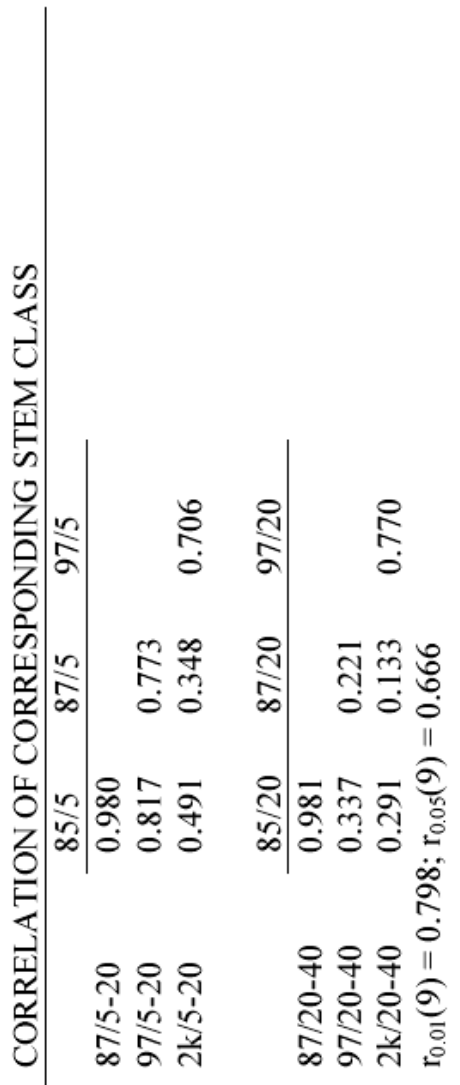




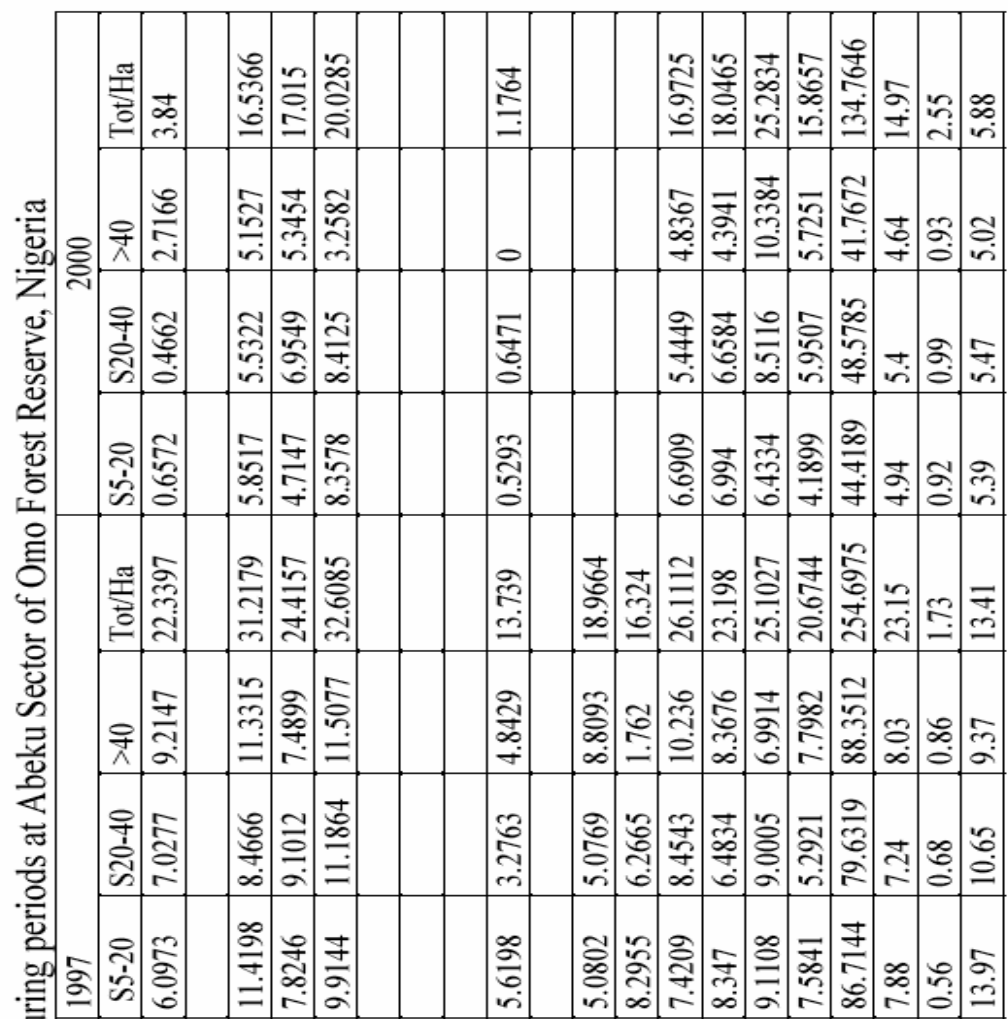

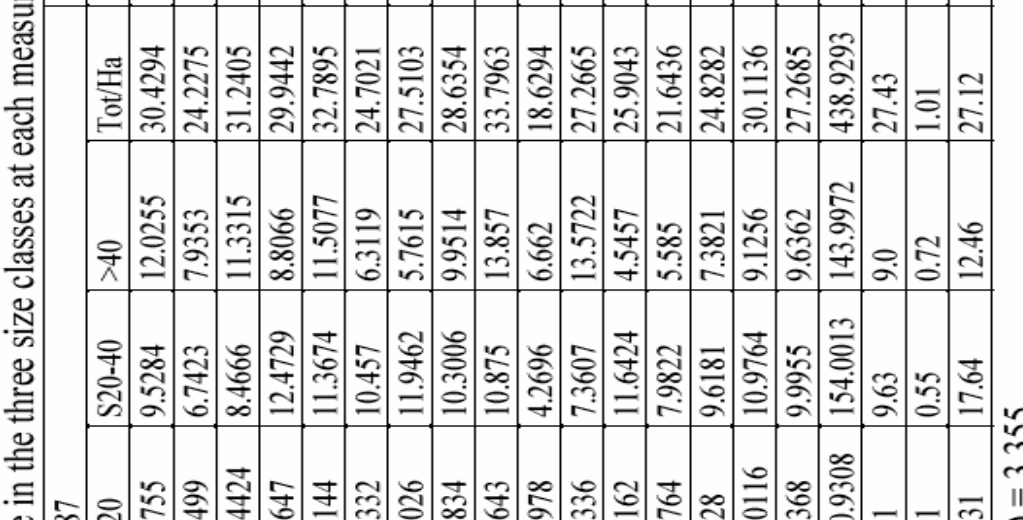

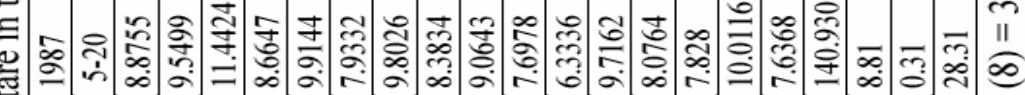
东

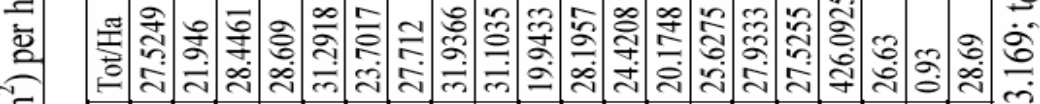

国

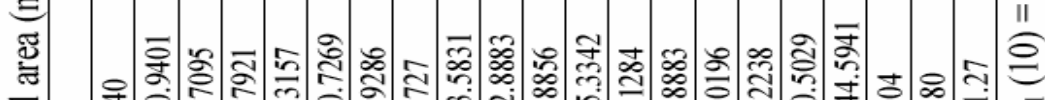

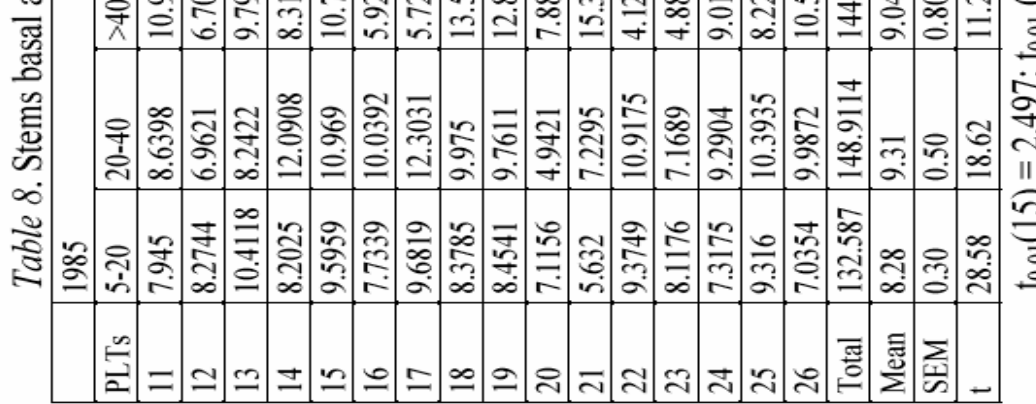

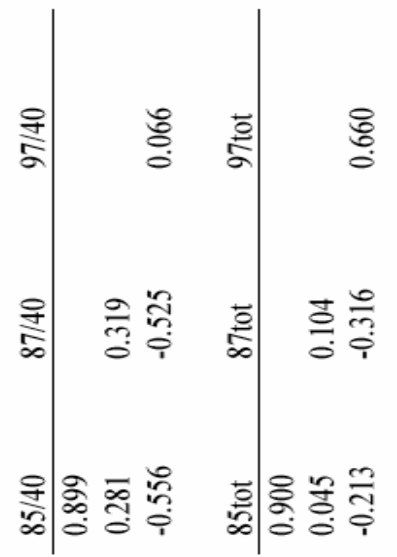

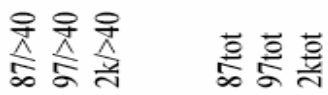

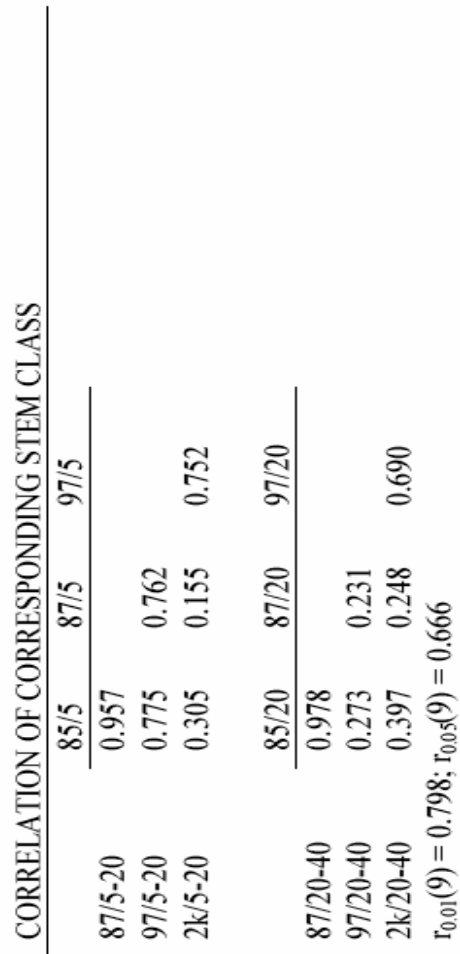


Table 9. Sorensen's similarity indices between sampling periods of nine plots available during the four measuring periods

\begin{tabular}{|l|c|c|c|c|}
\hline & $\mathbf{1 9 8 5}$ & $\mathbf{1 9 8 7}$ & $\mathbf{1 9 9 7}$ & $\mathbf{2 0 0 0}$ \\
\hline No. of tree species & 92 & 97 & 93 & 71 \\
\hline 1985 & & 86.46 & 72.90 & 69.79 \\
\hline 1987 & & & 88.12 & 73.20 \\
\hline 1997 & & & & 74.47 \\
\hline 2000 & & & & \\
\hline
\end{tabular}

natural rainforest. The values compared favourably with other parts of the Nigerian rainforest (Ojo, 1990; Okali and Ola-Adams, 1987 and Ojo and Ola-Adams, 1996). The five plots lost between 1987 and 1997 and additional two plots between 1997 and 2000 should be a serious concern and indicates the level of dereservation/deforestation in the study site and by extension most parts of the Nigerian rainforest. These have serious implications on global climate. It is a matter for verification to confirm if the remaining nine plots have not been converted to plantations of arable and cash crops. It should be noted that the ten plots at the Sawmill sector of the forest reserve (Table 1) had earlier been converted to monocultural plantations of Gmelina, Teak and Pines. It will be necessary to investigate what is going on in other EEC/HFMP plots in other parts of the rainforest of southern Nigeria viz. Owan, Sapoba, Oban East and Oban West (Table 1).The low values of all the parameters assessed in 1997 and 2000 may not entirely be due to the loss of these plots but also to the encroachment of the remaining plot which depleted them of small, medium and large trees. One of the reasons why deforestation of reserved forest especially the research sample plots, is made easy is the interval between measurement and remeasurements which results in near neglect of the plots. For example, ten years (1987-1997) as in this study, is a long time to abandon research plots at the centre of a rainforest surrounded by enclaves. However, possibility of encroachment will be reduced if the plots are frequently visited and assessed. The fact that additional tree species and families were found in 1987 enumeration showed that if continuous and consistent enumerations were carried out at constant intervals, tree diversity would have improved with subsequent enumeration.

The high values of parameters measured in 1985 and 1987 confirmed that if the forest is properly managed and protected, there will be increased turnover as reported for other forest in the tropics (Phillips, 1996). It is therefore necessary that the remaining forests especially those in research plots should be properly maintained and periodically assessed to be able to achieve the purposes for which they were established, which is to monitor their diversity and development through time. This is very essential as tropical forest support more than half of all species on earth and also because of the important role of tropical forests in amelioration of climate. The original plan for the EEC/HFMP was to assess them at 2-years interval. The attainment of this objective cannot be achieved without international assistance to enhance their continuous assessment. Tropical forest anywhere in the world is a great asset to humankind. Their wanton destruction at this time, when researches are still going on to determine the uses of their numerous resources (especially plants) and potentials will deny both present and future generations of these benefits.

\section{REFERENCES}

Hutchinson J. and Dalziel J.M. (1954-72), Flora of West Tropica Africa, ed.2, Revision editors Keay R.J.W. (Vol. 1) and Happer F.N (Vols II \& III), Crown Agents.

Keay R.W.J.(1989), Trees of Nigeria, Clarendon Press, Oxford.

Lowe J. and Soladoye, M.O. (1990), Some changes and corrections to names of Nigerian plants since publication of Flora of West Tropical Africa, ed. 2., Nigerian Trees, Nig. J. Botany 3, 1-24.

Ojo L.O. (1990), High forest veariation in southern Nigeria: implications for conservation and Management, Ph.D. thesis, University of Wales, Bangor, U.K. 
Ojo, L.O. (1993), Estimation of carbon dioxide uptake and emission from deforestation of the Nigerian forests, Nigerian Journal of Forestry, 23, 33-41.

Okali D.U.U. and Ola-Adams B.A. (1987), Tree population changes in treated rainforest at Omo forest reserve, south-western Nigeria, Journal of Tropical Ecology, 3, 291-313.

Ola-Adams B.A. (1999), Biodiversity inventory of Omo Biosphere reserve, Nigeria. Country report on Biosphere reserve for biodiversity conservation and sustainable development in Africa (BRAAF) project, eds. Ola-Adams B.A.

Ola-Adams B.A., Ojo L.O. and Adetunji M.T. (1998), Accumulation of nutrient under different forest land uses, Nigerian Journal of Forestry, 28, 5-14.

Pelou E.C. (1984), The interpretation of ecological data: a primer on classification and ordination, eds. Wiley - Interscience, New York, pp 263.

Phillips O.L. (1996), Long term environmental changes in tropical forests: increasing tree turnover, Environmental Conservation, 23, 235-248.

Appendix 1. Total number of stems per species at each of the measuring years

\begin{tabular}{|c|c|c|c|c|c|c|c|c|}
\hline S/n & PL & & & & TOTA & L STE & & \\
\hline & CODE & SPECIES NAME & FAMILY & HABIT & 1985 & 1987 & 1997 & 2000 \\
\hline 1 & ACDJ & Anthocleista djalonensis & Loganiaceae & Tree & 16 & 5 & 4 & 2 \\
\hline 2 & ADGE & Aidia genipiflora & Rubiaceae & Tree & 1 & 30 & 5 & 4 \\
\hline 3 & ADLA & Antidesma laciniatum & Euphorbiaceae & Tree & 6 & 13 & 12 & 6 \\
\hline 4 & AFAF & Afzelia africana & Caesalpinioidae & Tree & 5 & 3 & 1 & 1 \\
\hline 5 & AIRO & Aningeria robusta & Sapotaceae & Tree & 1 & 1 & & \\
\hline 6 & ALFE & Albizia feruginea & Mimosoideae & Tree & 8 & 6 & 4 & 1 \\
\hline 7 & ALZY & Albizia zygia & Mimosoideae & Tree & & 1 & & \\
\hline 8 & ANAF & Antiaris toxicaria & Moraceae & Tree & 15 & 15 & 12 & 6 \\
\hline 9 & AOMA & Annimidium mannii & Annonaceae & Tree & 3 & 4 & 2 & \\
\hline 10 & ASAU & Anthonatha aubryanum & Euphorbiaceae & Tree & 90 & 99 & 83 & 63 \\
\hline 11 & ASBO & Alstonia boonei & Apocynaceae & Tree & 1 & 1 & & \\
\hline 12 & ASCO & Alstonia congensis & Apocynaceae & Tree & 13 & 14 & 4 & 2 \\
\hline 13 & ATFR & Anthonatha fragrans & Euphorbiaceae & Tree & 25 & 25 & 8 & 4 \\
\hline 14 & ATMA & Anthonotha macrophylla & Caesalpiniodeae & Tree & 9 & 12 & 1 & 1 \\
\hline 15 & AYMI & Antrocaryon micraster & Anacardiaceae & Tree & & 1 & 1 & \\
\hline 16 & BDMI & Bridelia micrantha & Euphorbiaceae & Tree & 9 & 1 & & \\
\hline 17 & BECO & Berlinia confusa & Caesalpinioidae & Tree & & 6 & 3 & 5 \\
\hline 18 & BOBU & Bombax buonopozense & Bombacaceae & Tree & 2 & 5 & 3 & \\
\hline 19 & BPNI & Baphia nitida & Papilionoideae & Tree & 5 & 4 & 3 & \\
\hline 20 & BPPU & Baphia pubescens & Papilionoideae & Tree & 2 & 3 & 1 & \\
\hline 21 & BREU & Brachystegia eurycoma & Caesalpinioidae & Tree & 2 & 1 & & \\
\hline 22 & BRNI & Brachystegia nigerica & Caesalpinioidea & Tree & 23 & 28 & 12 & 7 \\
\hline 23 & BTFI & Bateria fistulosa & Passifloraceae & Tree & & 1 & & \\
\hline 24 & BUCO & Buchholzia coriacea & Capparaceae & Tree & & 15 & 9 & 6 \\
\hline 25 & CASU & Canthium subcordatum & Rubiaceae & Tree & 16 & 14 & 7 & 2 \\
\hline 26 & CAVU & Canthium vulgare & Rubiaceae & Tree & 4 & 2 & 1 & 1 \\
\hline 27 & CBPE & Ceiba pentandra & Bombacaceae & Tree & 6 & 6 & 4 & 1 \\
\hline 28 & CEMI & Celtis milbraedii & Ulmaceae & Tree & 17 & 16 & 12 & 6 \\
\hline 29 & CEZE & Celtis zenkeri & Ulmaceae & Tree & 20 & 21 & 12 & 7 \\
\hline 30 & $\mathrm{CF}$ & Coffea sp & Rubiaceae & Tree & & 5 & 2 & 1 \\
\hline 31 & CJPA & Corynanthe pachyceras & Rubiaceae & Tree & & 8 & 4 & 2 \\
\hline 32 & CKPL & Chrysophyllum albidum & Sapotaceae & Tree & & 1 & 1 & \\
\hline 33 & CLPA & Cleistopholis patens & Annonaceae & Tree & 38 & 42 & 17 & 10 \\
\hline 34 & $\mathrm{COAC}$ & Cola accuminata & Sterculiaceae & Tree & 12 & 6 & 2 & \\
\hline 35 & COGI & Cola gigantea & Sterculiaceae & Tree & & 1 & & \\
\hline 36 & CPPR & Carapa procera & Meliaceae & Tree & 1 & 4 & 1 & \\
\hline 37 & CQCE & Craterispermum cerinanthum & Rubiaceae & Tree & 2 & 2 & 2 & 1 \\
\hline 38 & CRMI & Cordia milenii & Boraginaceae & & & & 2 & \\
\hline
\end{tabular}




\begin{tabular}{|c|c|c|c|c|c|c|c|c|}
\hline $\mathbf{S} / \mathbf{n}$ & PL & & & & TOT & L STE & & \\
\hline & CODE & SPECIES NAME & FAMILY & HABIT & 1985 & 1987 & 1997 & 2000 \\
\hline 39 & CRPL & Cordia platthyrsa & Boraginaceae & Tree & 32 & 36 & 23 & 11 \\
\hline 40 & CXHE & Claoxylon hexandrum & Euphobiaceae & Tree & 1 & 12 & 7 & 4 \\
\hline 41 & DAOL & Daniellia olliveri & Caesalpinioidea & Tree & & 1 & 1 & \\
\hline 42 & DGCA & Discoglypremna calonuera & Euphorbiaceae & Tree & 60 & 60 & 30 & 15 \\
\hline 43 & DIAL & Diospyros iturensis & Ebenaceae & Tree & 332 & 327 & 151 & 55 \\
\hline 44 & DICR & Diospyros crassiflora & Ebenaceae & Tree & 5 & 5 & & \\
\hline 45 & DIDE & Diospyros dendo & Ebenaceae & Tree & 205 & 185 & 89 & 33 \\
\hline 46 & DIPI & Diospyros insculpta & Ebenaceae & Tree & 2 & 1 & & 19 \\
\hline 47 & DIPI & Diospyros piscatoria & Ebenaceae & Tree & 44 & 105 & 53 & \\
\hline 48 & DISU & Diospyros suaveolens & Ebenaceae & Tree & 128 & 153 & 76 & 25 \\
\hline 49 & DIUN & Diospyros undabunda & Ebenaceae & Tree & 1 & 12 & 5 & 3 \\
\hline 50 & DLGU & Dialium guineense & Caesalpinioidae & Tree & & 2 & 1 & \\
\hline 51 & DR & Drypetes $\mathrm{sp}$ & Euphorbiaceae & Tree & 9 & & & \\
\hline 52 & DRAF & Drypetes aframensis & Euphorbiaceae & Tree & 13 & 8 & 3 & 2 \\
\hline 53 & DRGI & Drypetes gilgiana & Euphorbiaceae & Shrub & 40 & 28 & 14 & 6 \\
\hline 54 & DRGO & Drypetes gossweileri & Euphorbiaceae & Shrub & 96 & 80 & 45 & 9 \\
\hline 55 & DRLE & Drypetes leonensis & Euphorbiaceae & Tree & 9 & 2 & 2 & 1 \\
\hline 56 & DRMO & Drypetes molunduana & Euphorbiaceae & Tree & 4 & 6 & 2 & 2 \\
\hline 57 & DRPA & Drypetes paxii & Euphorbiaceae & Tree & & 1 & & \\
\hline 58 & DRST & Drypetes staudtii & Euphorbiaceae & Tree & & & 1 & \\
\hline 59 & DSBE & Disthemonanthus benthamianum & Caelsalpinioideae & Tree & 4 & 4 & & \\
\hline 60 & DTAR & Dictyandra arborscens & Rubiaceae & Shrub & 15 & 15 & 6 & \\
\hline 61 & DX & Dracaena $\mathrm{sp}$ & Agavaceae & Shrub & 4 & 4 & 1 & \\
\hline 62 & ENAN & Entandrophragma angolense & Meliaceae & Tree & 7 & 4 & 2 & \\
\hline 63 & ENCA & Entandrophragma candolii & Meliaceae & Tree & 3 & 1 & 1 & 2 \\
\hline 64 & ERIV & Erythrophleum ivorense & Caesalpinioideae & Tree & 18 & 18 & 8 & 5 \\
\hline 65 & ETCH & Enantia chlorantha & Annonaceae & Tree & 13 & 13 & 8 & 1 \\
\hline 66 & FAMA & Zanthoxylum macrophylla & Rutaceae & Tree & 29 & 28 & 20 & 5 \\
\hline 67 & FIEX & Ficus exasperata & Moraceae & Tree & 1 & 1 & 2 & \\
\hline 68 & FIMU & Ficus mucoso & Moraceae & Tree & 1 & 1 & & \\
\hline 69 & FUEL & Funtumia elastica & Apocynaceae & Tree & 59 & 59 & 37 & 22 \\
\hline 70 & GCKO & Garcinia kola & Guttiferae & Tree & & 1 & & \\
\hline 71 & GRCO & Grewia coriacea & Tiliaceae & Shrub & 31 & 37 & 21 & 15 \\
\hline 72 & GUCE & Guarea cedrata & Meliaceae & Tree & 8 & 4 & 2 & 1 \\
\hline 73 & GUTH & Guarea thomsonii & Meliaceae & Tree & 1 & 2 & 2 & \\
\hline 74 & HOAF & Homallium africanum & Samydaceae & Tree & 1 & 5 & 2 & \\
\hline 75 & HOAY & Homallium aylmeri & Samydaceae & Tree & 1 & 2 & 2 & \\
\hline 76 & HOLE & Homalium letestui & Samydaceae & Tree & 1 & 3 & & 5 \\
\hline 77 & HSZE & Hypodaphinis zenkeri & Irvinginacea & e Tre & & 6 & 2 & \\
\hline 78 & HUUM & Hunteria umbellata & Apocynaceae & Tree & 95 & 93 & 63 & 24 \\
\hline 79 & IRGA & Irvingia gabonensis & Irvinginaceae & Tree & 4 & & & \\
\hline 80 & KHIV & Khaya ivorensis & Meliaceae & Tree & 17 & 17 & 6 & 2 \\
\hline 81 & KLGA & Klainedoxa gabonensis & Irvinginaceae & Tree & 4 & 4 & 2 & \\
\hline 82 & LAWE & Lannea welwitchii & Anacardiaceae & Tree & 1 & & & \\
\hline 83 & LOTR & Lovoa trichilioides & Meliaceae & Tree & 12 & 13 & 9 & 2 \\
\hline 84 & MCBA & Macaranga barteri & Euphorbiaceae & Tree & 93 & 103 & 37 & 14 \\
\hline 85 & MDPU & Microdesmis puberula & Euphorbiaceae & Shrub & 2 & 3 & 2 & 1 \\
\hline 86 & MEEM & Maesopsis eminii & Rhamnaceae & Tree & & 5 & 1 & \\
\hline 87 & MICI & Mitragyna ciliata & Rubiaceae & Tree & 21 & 25 & 14 & 9 \\
\hline 88 & MNMY & Monodora myristica & Annonaceae & Tree & 10 & 9 & 2 & \\
\hline 89 & MUCE & Musanga cecrepioides & Moraceae & Tree & 24 & 25 & 7 & 1 \\
\hline 90 & NADI & Nauclea diderichii & Rubiaceae & Tree & 12 & 12 & 4 & 1 \\
\hline 91 & NBLA & Newbouldia laevis & Bignoniaceae & Tree & & 1 & 1 & \\
\hline 92 & OLAN & Octolobus spectabilis & Sterculiaceae & Tree & 231 & 248 & 124 & 32 \\
\hline 93 & PCMA & Penthacletha macrophyla & Mimosoideae & Tree & 4 & 4 & 3 & 3 \\
\hline
\end{tabular}




\begin{tabular}{|c|c|c|c|c|c|c|c|c|}
\hline $\mathbf{S} / \mathbf{n}$ & PL & & & & TOT & L STE & & \\
\hline & CODE & SPECIES NAME & FAMILY & HABIT & 1985 & 1987 & 1997 & 2000 \\
\hline 94 & PHDI & Phyllanthus discoides & Euphorbiaceae & Tree & 5 & 17 & 6 & 3 \\
\hline 95 & PIAF & Piptadeniastrum africanum & Mimosoideae & Tree & 1 & 1 & & \\
\hline 96 & PMSU & Greenwayodendron suaveolens & Annonaceae & Tree & & 1 & 1 & 1 \\
\hline 97 & PRCL & Porterandia clandatha & Rubiaceae & Tree & 49 & 25 & 12 & 3 \\
\hline 98 & PUJO & Pausinystalia johimbe & Rubiaceae & Tree & 5 & 7 & 2 & 2 \\
\hline 99 & PUMA & Pausinystalia macroceras & Rubiaceae & Tree & & 4 & 3 & 1 \\
\hline 100 & PUTA & Pausinystalia talbotii & Rubiacea & Tree & 33 & 25 & 8 & 4 \\
\hline 101 & PXAR & Polysphaera arbuscula & & Shrub & 1 & & & \\
\hline 102 & PYAN & Pycnanthus angolense & Myristicaceae & Tree & 8 & 9 & 6 & 3 \\
\hline 103 & RIHE & Ricinodendron heudelotii & Euphorbiaceae & Tree & 34 & 35 & 21 & 10 \\
\hline 104 & RNOB & Rinorea oblongifolia & Violaceae & Tree & 43 & 31 & 10 & 5 \\
\hline 105 & ROHI & Rothmania hispida & Rubiaceae & Tree & 83 & 78 & 40 & 21 \\
\hline 106 & RVVO & Rauvolvia vomitoria & Apocynaceae & Shrub & 15 & 17 & 4 & 1 \\
\hline 107 & SBPU & Stombosia pustulata & Olacaceae & Tree & 283 & 283 & 187 & 74 \\
\hline 108 & SCCO & Scottellia coriacea & Flacourtaceae & Tree & 70 & 69 & 29 & 17 \\
\hline 109 & SPCA & Spathodea campanulata & Bignoniaceae & Tree & 3 & 1 & & \\
\hline 110 & STOB & Sterculia oblonga & Sterculiaceae & Tree & 7 & 1 & 1 & 1 \\
\hline 111 & STRH & Sterculia rhinopetala & Sterculiaceae & Tree & 52 & 54 & 38 & 29 \\
\hline 112 & SUST & Staudtia stipitata & Myristicaceae & Tree & 1 & & & \\
\hline 113 & TAPA & Tabernaemontana pachysiphon & Apocynaceae & Tree & 263 & 283 & 154 & 72 \\
\hline 114 & TESU & Terminalia superba & Combretaceae & Tree & 35 & 37 & 11 & 2 \\
\hline 115 & THEM & Trichilia emetica & Meliaceae & Tree & 29 & 18 & 3 & \\
\hline 116 & THMO & Trichilia monadelpha & Meliaceae & Tree & 2 & & & \\
\hline 117 & UA & Uapaca sp & Euphorbiaceae & Tree & 1 & & & \\
\hline 118 & $\mathrm{XY}$ & Xylopia spp & Annonaceae & Tree & 29 & 18 & 6 & 3 \\
\hline
\end{tabular}

